\title{
Impact of Red Sea on Climate of A Coastal and An Inland City in the Kingdom of Saudi Arabia
}

\author{
Huda Abdullah E. Alabbad*
}

\begin{abstract}
We analyzed the impact of the Red Sea on the climatic features of Tabukand Yanbuin the Kingdom of Saudi Arabia and used various comfort indices to determine the most suitable climatic conditions for these cities. We found that there is a clear difference between Tabuk and Yanbu with respect to the length of their comfort periods.Tabuk experiences cold periods throughout the year, with the temperature reaching the freezing point. Further, there are periods of climatic variability in Yanbu whereinthe temperaturefluctuates between hot and very cold. Furthermore, there are several periods of thermal discomfort in Tabuk and Yanbu, especially during the winter and summer. [Bul. Soc. Géog. d'Égypte, 2020, 93: 54-80]
\end{abstract}

Key Words: Human comfort, Effective temperature, Wind chill index, Thermal discomfort index.

\section{Introduction}

Climate is one of the most important natural parameters affectingthe physiological and psychological comfort of humans as well as their activities and movement, and its effect may bethe both direct and indirect. Therefore, climate and weather conditions play a primary role in determining the human comfort as well as theplaces where humans feel comfort. They also determine the nature and quality of the food grown, type of clothes worn, and nature of people's daily activities.

The human sense of comfort depends on several factors related to the environment. However, the characteristics that determine the human feeling of comfort or boredom can differ from individual to individual, and so do the methods used to measure this feeling of comfort. It is well known that humans feel comfortable under certain weather conditions that are in keeping with the human body temperature of $37{ }^{\circ} \mathrm{C}$ (Shehadeh, 1983). It is also known that the prevailing weather conditions directly affect human comfort, behavior, and productivity more than any other element of the living environment. However, reactions to fluctuations in the weather will vary from one person to another based on their physiology, sex, current state of health, quality of food and clothing, and the extent of their adaptation to the

* Professor of Climate Geography, Faculty of Arts, Princess Nourah Bint Abdulrahman University, KSA.

For Correspondence: e-mail: haalabbad@pnu.edu.sa 
external environment. Humans live in a medium with which they exchange energy. The human body generates internal energy through the conversion of food in order to match the weather fluctuations. Humans may be exposed to sun stroke, if the temperature rises, or freeze, if the temperature drops to an unbearable level (Musa, 2002).

\subsection{Relevant Background:}

Several studies have addressed the subject of climate and its impact on human comfort. Bakharjy (1989) conducted a study using Thom's thermal discomfort index, emphasizing its usefulness in places such as Saudi Arabia. Aljukhaydib (1991) presented a study at the Fourth Geographic Seminar held by the geography departments of various universities in Saudi Arabia where the author used Thom's and Terjung's indices to confirm that extreme thermal discomfort is experienced during the summer and that some discomfort occurs in the autumn, as the daytime temperature is too high but reduces at night. Similarly, Suliman (1999) presented a study at the Fourth Geographic Symposium of the geography departments of Saudi Arabian universities wherein Lukai's index was used with detailed daily data for more than five years toanalyze and identify hot and cold periods during the year. The aim was to propose design alternatives and architectural guidelines for the construction of buildings and roads in Mecca that provide the maximum degree of thermal comfort. Qerba (2004) conducted a study that highlighted the importance of meteorology and bioclimate studies in regions with harsh climates. The author recommended that the expansion of urbanization in the capital of Saudi Arabia be reconsidered, that plans leading to open urban centers similar to those found in capital cities around the world be adopted, and that afforestation be encouraged. Habib (2004) studied the physiological comfort of the residents of Saudi Arabia with the aim of improving tourism,providing therapeutic benefits, and aiding the military. The original model was not suitable for Saudi Arabia, and the author modified it slightly to obtain better results. Habib (2006) conducted another study to analyze the so-called warming and cooling "degree days" basedon a method developed by Thom (1959).The study took into account the variations in the temperature thresholds in eastern Saudi Arabia and their effect on energy use. Based on the results, the author produced a map of the thermal boundaries in the eastern region.

All these studies dealt with the subject of climate and its impact on human comfort from multiple aspects in different areas using various mathematical models and indices. However, to the best of our knowledge, there has been no previous study on the climates of Tabuk and Yanbu cities in Saudi Arabia. In addition, thenovelty of the current study is that severaldifferent indicesare used to analyze the climates of the two cities. 


\subsection{Study Problem and Questions:}

The Kingdom of Saudi Arabia is a large country that is surrounded by the Red Sea from the west and the Arabian Gulf from the east. It is characterized by climatic variations as it experiences different climatic patterns. This means that the climatic comfort levels for the various seasons differ from one region to another. Therefore, the climatic comfort levels in the Kingdom must be studied in detail in all regions in order to determine the most appropriate activity for each region and season and to elucidate the nature of climate comfort and thermal discomfort. Therefore, in this study, we focused on some of the most widely indices such as the effective temperature based on Gaffney's coefficient, Siple and Passel's wind chill index, and Thom's model to determine the comfort levels for two cities. Yanbu (a coastal city) and Tabuk (an inland city) were chosen for this study because of their different geographic locations, latitudes and longitudes, and elevations above sea level, as these differences would allow for a ready comparison between the cities. This study addressed the following questions:

1. Is there any similarity between the months of comfort in the selected cities inthe summer?

2. What is the impact of the Red Sea on the study areas?

3. Does the climate affect the human psychological and physiological comfort in the study areas?

4. Is it possible to determine the comfort areas and comfort months based on the criteria for thermal comfort?

5. Is it possible to use different climate comfort indices in the case of the study areas?

\subsection{Study Importance and Objectives:}

This study aimed to determine the levels of climate comfort and thermal discomfort for two locations, namely, an inland city (Tabuk) and a coastal one (Yanbu), in order to identify the main areas of climate comfort and thermal discomfort which in turn reflect on human activities and practices in their environment.

This subject was chosen for several reasons:

1. It isessential to determine the relationship between various climate variables and theactivity and sense of comfort or discomfort of individuals.

2. To comprehensively study the climatic conditions and indices that affect the study areas.

3. To analyze the effects of the difference in the locations of Tabuk and Yanbu cities in terms of their distance from the Red Sea coast, which may result in different climatic conditions and allow for a clear comparison between the sites. 
4. To study the climate comfort and thermal discomfort in the study areas in order to identify the appropriate activities for both cities, reduce the negative effects of the climate on human activity, and identify areas suitable for the expansion of tourism.

Based on this, the study aimed to achieve the following goals:

1. To identify the factors influencing the climates of the study areas.

2. To identify the climatic features of Tabuk and Yanbu stations and elucidate the differences between them.

3. Link the climate variables and human comfort using biological indices.

4. To assess the effectiveness of applying comfort indices in the study areas.

5. To measure the human thermal comfort levels and identify the most suitable climate conditions for achieve the desired levels of comfort.

6. Compare the results on which human activity and practices depend in the environment.

\section{Materials and Methods}

The study was based mainly on the inductive method, which begins from the more specific and ends with the more general. Quantitative analysis was performedon the available statistical data provided by the meteorological stations. Furthermore, the descriptive method was also used during the analysis.

\subsection{Data Processing and Analysis:}

- Descriptive statistics were used to calculate the monthly frequencies and averages of the geographic climate variables and to analyze the relationships between the various indices.

- The results are illustrated using graphs. Further, equations and indices were used to calculate the results.

- The most widely used climate comfort indices for quantifying human comfort were used to analyzethe study areas. These indices focus on the most significant climate variables that affect human comfort, namely, the temperature, relative humidity, and wind speed. The indices used were as follows:

a. Effective temperature (ET) calculated using Gaffney's coefficient: In 1973, Gaffney proposed a classification scale for the level of comfort that humans feel and to describe the corresponding effective temperature (Musa 2002). He compiled this classification scale for the effective temperatures after conducting a series of experiments in the interiors of Australia on people wearing normal clothing andplaced in thesitting position. These experiments led to the classification of the 
various types of comfort that humans experience in response to thetemperature.

b. Siple and Passel's wind chill index:

In 1945, Siple and Passel proposed a mathematical model that yields a wind index reflective of the amount of heat absorbed by the wind from an exposed surface with an area of $1 \mathrm{~m}^{2}$. This model is used to measure the human response to changes in the temperature, relative humidity, and wind speed based on the loss of energy from $1 \mathrm{~cm}^{2}$ of normal human skin exposed to air for $1 \mathrm{~h}$. The value of the wind chill index as per this model is calculated as follows (Musa 2002):

$$
K=(10 \sqrt{v}+10.45-v)(33-\mathrm{T})
$$

where: $\mathrm{K}=$ cooling rate owing tothe effect of the wind as measured based on the energy lost by $1 \mathrm{~m}^{2}$ of the human body exposed to air for $1 \mathrm{~h}(\mathrm{Cal} / \mathrm{h})$

$\mathrm{T}=$ temperature $\left({ }^{\circ} \mathrm{C}\right)$

$\mathrm{V}=$ wind speed $(\mathrm{mph})$

\section{c. Thom's thermal discomfort index}

Thom (1959) developed a measure for the thermal stress called the thermal discomfort index in order to determine the degree of human comfort under certain climatic conditions depending on the temperature and relative humidity (Thom 1959). This index is calculated using the following equation:

$$
\mathrm{DI}=\left(\mathrm{T}_{\mathrm{d}}\right)-[(0.55) *(1-\mathrm{RH})]\left(\mathrm{T}_{\mathrm{d}}-14.5\right)
$$

where: $\quad \mathrm{DI}=$ thermal discomfort index

$\mathrm{RH}=$ relative humidity as a fraction of 1

$\mathrm{Td}=$ dry bulb temperature

This is the model used most often in bioclimate studies. Using a sample of people's responses to different temperatures and humidity, Thom discovered the following (Musa, 2002):

- at $21>\mathrm{DI}, 100 \%$ of the people feel complete comfort

- at $21>\mathrm{DI}>24,50 \%$ of the people feel relative comfort

- at $24>\mathrm{DI}>27,100 \%$ of the people feel discomfort

- $\quad$ at DI $>27,100 \%$ of the people feel extreme discomfort

- at DI $>29$, stress is evident

\subsection{Data sources}

- Library sources: The study areaswere determined after surveying the available sources and information on the region from geography books and theses as well asthe scientific literature related to the subject of this study. 
- Statistical sources: We used the records of the General Authority of Meteorology and Environmental Protection in Jeddah from 1978 to 2015. This period was considered long enough to provide an average of the climate in the study areas.

\section{Study Areas}

Tabuk Cityis located at $36^{\circ} 24^{\prime} 44^{\prime \prime} \mathrm{E}$ and $28^{\circ} 23^{\prime} 50^{\prime \prime} \mathrm{N}$ and is 760 meters above sea level. It is approximately $700 \mathrm{~km}$ from Madinah due north and approximately $1350 \mathrm{~km}$ from Riyadh.Tabuk is located in a low valley and is known as the north gate owing to its distinct geographical location overlooking the western Red Sea and the Aqaba Gulf with long shores (Ministry of Municipal and Rural Affairs, Municipality of Tabuk, tabukm.gov.sa).

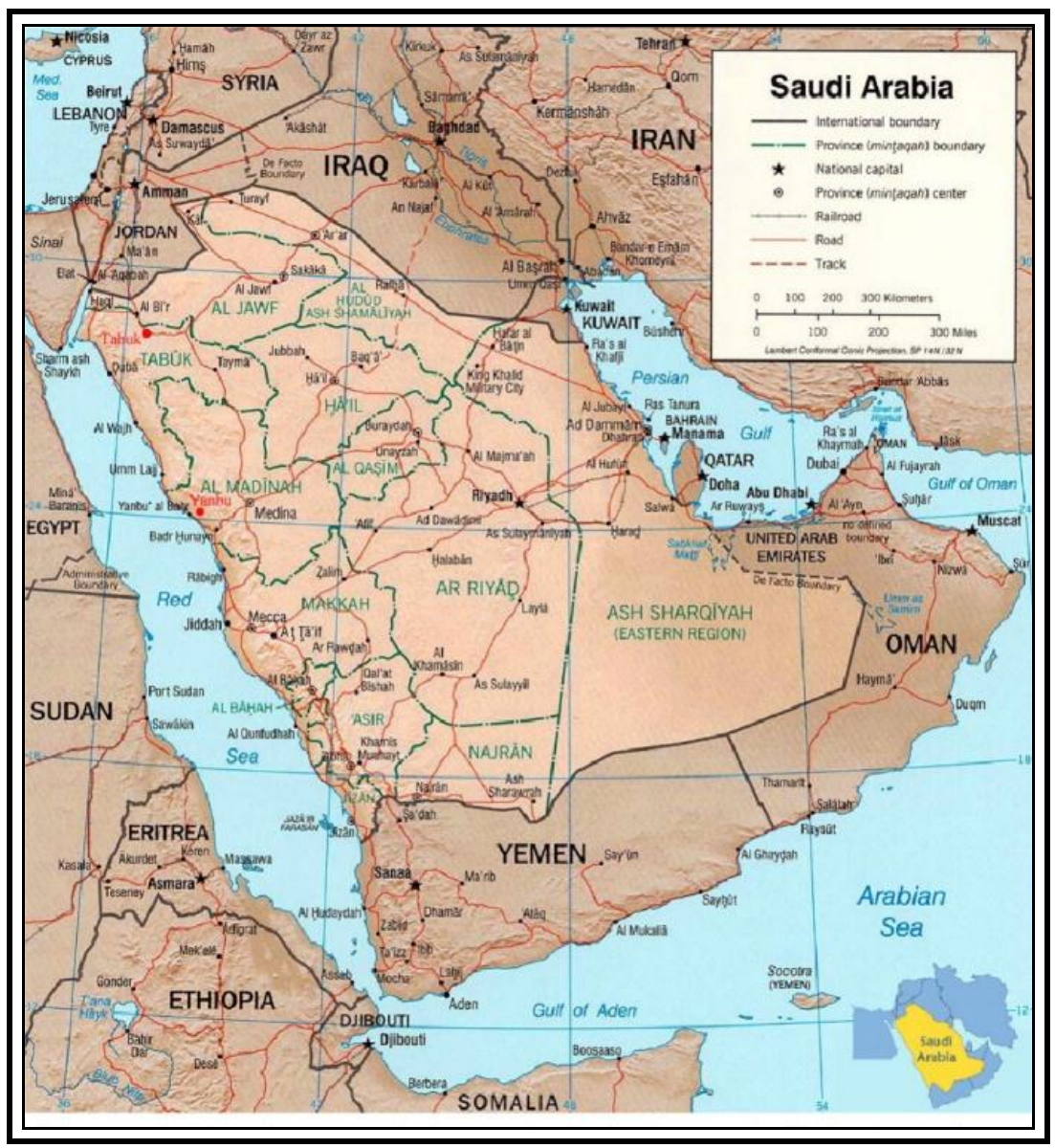

Figure 1. Study area, which is shown in light brown;

Tabuk and Yanbu cities are indicated by red dots. 
Yanbu City is located at $38^{\circ} 01^{\prime} 35^{\prime \prime} \mathrm{E}$ and $24^{\circ} 11^{\prime} 12^{\prime \prime} \mathrm{N}$ and 15 meters above sea level. It is one of the governorates of Madinah, located approximately $200 \mathrm{~km}$ west of Madinah, $300 \mathrm{~km}$ south of Alwajh City, and $300 \mathrm{~km}$ north of Jeddah. The population of Yanbu City is estimated to be 500,000, and it is the second largest city along the Red Sea after Jeddah. The city, known as the Red Sea Pearl, is divided into three areas: Yanbu Al Nakhal (the Palms), Yanbu Al Bahr (the Sea Yanbu) and Yanbu Al-Sinaiyah (Industrial Yanbu) (Ministry of Municipal and Rural Affairs, Municipality of Madinah, amanamd.gov.sa). The borders of the study area are illustrated in Figure 1.Before studying the main climate elements of the two locations, we identified the many variables that affect the climate of the areas, the most important of which are discussed below.

\subsection{Latitude and Longitude:}

The amount of solar radiation falling on the earth's surface varies with the place where the sun is directly overhead, and this changes with the season. The sun is directly above the Tropic of Cancer $\left(23.5^{\circ} \mathrm{N}\right.$, northern summer) and the Tropic of Capricorn (23.5 ${ }^{\circ} \mathrm{S}$, southern summer) and above the Equator in the spring and autumn.

As mentioned above, Tabuk is located at $36^{\circ} 34^{\prime} 44^{\prime \prime} \mathrm{E}$ and $28^{\circ} 23^{\prime} 50^{\prime \prime} \mathrm{N}$. Yanbu is also located on the Red Sea, in western Saudi Arabia at $38^{\circ} 01^{\prime} 35^{\prime \prime} \mathrm{E}$ and $24^{\circ} 11^{\prime} 12^{\prime \prime} \mathrm{N}$. The Tropic of Cancer $\left(23.5^{\circ} \mathrm{N}\right)$ passes south of both locations. Thus, the two cities are located on the tropical circles extending from this latitude $18-30^{\circ}$ northward. As a result, desert conditions prevail in both cities, affecting their temperature. Further, in both cities, solar radiation increases during the summer as a result of the length of the day when the sun is directly above the Tropic of Cancer. In winter, the amount of incoming solar radiation reduces.

\subsection{Geographic locations of study areas:}

Yanbu and Tabuk are located on the western coast of the Red Sea in western Saudi Arabia. Yanbu's location on the Red Sea affects its climate, particularly its temperature and humidity, with its temperature being lower duringthe summer.However, the temperature during winter does not decrease much as compared to the case for the inland cities located far away from the sea.

Tabuk is located far from the sea and is considered an inland region. In addition, because of its elevation, its temperature and humidity are lower. The average temperature in Tabuk reaches $12{ }^{\circ} \mathrm{C}$ in the winter and $30.7^{\circ} \mathrm{C}$ in 
the summer. On the other hand, in Yanbu, the average temperature reaches $21.4{ }^{\circ} \mathrm{C}$ inthe winter and $31.4{ }^{\circ} \mathrm{C}$ inthe summer.

\subsection{Terrain:}

The altitude (height above sea level) of a place is an important factor influencing its weather and climate (Ahmed 1993); as the altitude increases, the temperature decreases. On comparing Tabuk and Yanbu, which havedifferent altitudes, one can see this effect in terms of the differences in the weather and climate of the two cities. The temperature in Tabuk, which is 760 meters above sea level, reaches an average of $31.2{ }^{\circ} \mathrm{C}$ in July, whereas that in Yanbu, which is 15 meters above sea level, reaches an average of $32.5^{\circ} \mathrm{C}$ in the same month.This is a clear indication of the effect of the altitude on the climate.

\subsection{Water Resources:}

The Red Sea borders Saudi Arabia in the west fora length of $1800 \mathrm{~km}$. The effect of the Red Sea is limited to the adjacent areas, as can be seen from a comparison of the relative humidities of the coastal and inland locations. In Jeddah, Yanbu, and Al Wajh, which are located on the coast, the annual relative humidity levels are 60,58 , and $67 \%$, respectively, while in the inland cities of Madinah, Riyadh, and Al Sulayyil,they are 24, 26, and 29\%, respectively (Ahmed, 1993).

Despite the dryness of these areas, their geological properties as well as their geomorphological and topographic characteristics have allowed some parts to be turned into agricultural areas with extensive valleys, such as the Al Rummah valley and Wadi Al Dawasir. Tabuk City is one of the main agricultural areas in Saudi Arabia (Ahmed, 1993).

\subsection{Climate features of study areas:}

The climate is one of the most important factors affecting people's lives and their economic and social conditions. It also contributes, together with the topography, to the formation ofthe natural environment in which people live. Despite great technological developments and progress, humans are still affected by the weather and climate of their environment, whichdetermine their quality of life, behavior, and daily activities.

\subsubsection{Wind speed:}

The wind speed varies from month to month over the course of the year. The coastal areas are more exposed to the wind throughout the year owing to the overlapping of the air masses over the sea and the daily local winds, which make the weather more pleasant. 
Tables (1) and (2) and Figure (2) show that the wind speed in Tabuk increases during the summer and autumn because of the activity of depressions. The wind speed reaches 7 knots in April and May and 6 knots in June, July, and August.

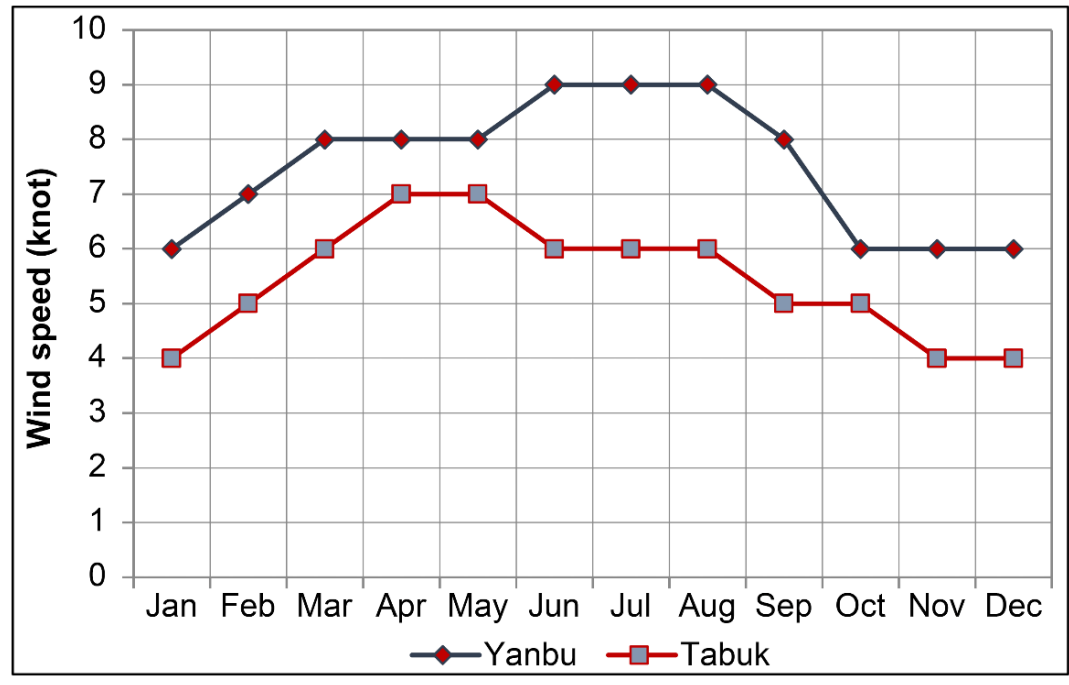

Figure 2. Comparison of monthly averages of wind speed in Tabuk and Yanbu for 1978-2015.

In Yanbu, the wind speed is moderately high throughout the year. The highest wind speed is observed during the spring and summer; in these seasons, the wind speed increases because of the activity of the depressions that start at the beginning of each season from autumn onwards. The highest wind speed is observed in the summer while the second highest wind speed is recorded in the spring. The average wind speed reaches 9 knots in June, July, and August and 8 knots in March, April, and May. Thus, the summer is ranked first in terms of the wind speed as the speed reaches 9 knots.

The impact of the geographic location on the wind speedcan be observed in the case of both cities as Yanbu is located on the Red Sea while Tabuk is located inland far away from the coast and at a greater altitude (the higher the altitude, the higher the wind speed).

\subsubsection{Temperature:}

The temperature in the study areas rises during the summer because they are located in a hot tropical region, where the sun is directly overhead for long periods throughout the year. The sky is also clear and free of clouds, thus increasing the amount of solar radiation received. This, in turn, 
increasesthe brightness of the sun. Tables (1) and (2) and Figure (3) show that the average temperatures in Tabuk in January and July are 10.8 and $31.2^{\circ} \mathrm{C}$, respectively. Further, the average temperatures in Yanbu in January and July are 21.3 and $32.5{ }^{\circ} \mathrm{C}$, respectively. The average temperatures decrease in the spring and autumn in both cities.

Table 1. Monthly averages of primary climate variables in Tabuk for 1978 to 2015.

\begin{tabular}{|l|c|c|c|c|c|}
\hline Month & $\begin{array}{c}\text { Wind } \\
\text { speed } \\
(\mathbf{k n o t})\end{array}$ & $\begin{array}{c}\text { Temperature } \\
\left({ }^{\circ} \mathbf{C}\right)\end{array}$ & $\begin{array}{c}\text { Relative } \\
\text { humidity } \\
(\mathbf{\%})\end{array}$ & $\begin{array}{c}\text { Pressure } \\
(\mathbf{m m h})\end{array}$ & $\begin{array}{c}\text { Precipitation } \\
(\mathbf{m m})\end{array}$ \\
\hline January & 4 & 10.8 & 49 & 929.6 & 1725.0 \\
\hline February & 5 & 13.0 & 41 & 927.2 & 4008.7 \\
\hline March & 6 & 17.0 & 34 & 926.7 & 3995.3 \\
\hline April & 7 & 22.5 & 26 & 925.1 & 3994.9 \\
\hline May & 7 & 26.5 & 23 & 924.8 & 2453.2 \\
\hline June & 6 & 29.8 & 21 & 923.1 & 3896.5 \\
\hline July & 6 & 31.2 & 22 & 921.3 & 2334.5 \\
\hline August & 6 & 31.2 & 24 & 921.9 & 1576.2 \\
\hline September & 5 & 28.8 & 27 & 924.7 & 3112.5 \\
\hline October & 5 & 24.0 & 32 & 927.5 & 5635.7 \\
\hline November & 4 & 17.3 & 43 & 929.0 & 4020.8 \\
\hline December & 4 & 12.2 & 49 & 930.0 & 4828.7 \\
\hline
\end{tabular}

Table 2. Monthly averages of primary climate variables in Yanbu for 1978 to 2015.

\begin{tabular}{|l|c|c|c|c|c|}
\hline Month & $\begin{array}{c}\text { Wind } \\
\text { speed } \\
(\mathbf{k n o t})\end{array}$ & $\begin{array}{c}\text { Temperature } \\
\left({ }^{\circ} \mathbf{C}\right)\end{array}$ & $\begin{array}{c}\text { Relative } \\
\text { Humidity } \\
(\mathbf{\%})\end{array}$ & $\begin{array}{c}\text { Pressure } \\
(\mathbf{m m h g})\end{array}$ & $\begin{array}{c}\text { Precipitation } \\
(\mathbf{m m})\end{array}$ \\
\hline January & 6 & 20.7 & 55 & 1013.6 & 1037.4 \\
\hline February & 7 & 21.3 & 55 & 1011.5 & 3140.7 \\
\hline March & 8 & 23.8 & 52 & 1007.7 & 2377.9 \\
\hline April & 8 & 27.3 & 51 & 1007.6 & 3125.1 \\
\hline May & 8 & 30.2 & 50 & 1005.7 & 2351.2 \\
\hline June & 9 & 31.9 & 52 & 1002.1 & 777.7 \\
\hline July & 9 & 32.5 & 55 & 1001.9 & 8.2 \\
\hline August & 9 & 32.8 & 56 & 1002.1 & 777.8 \\
\hline September & 8 & 32.0 & 56 & 1004.4 & 3889.8 \\
\hline October & 6 & 29.6 & 59 & 1007.8 & 1710.2 \\
\hline November & 6 & 25.8 & 56 & 1011.0 & 1855.6 \\
\hline December & 6 & 22.3 & 56 & 1013.2 & 1882.0 \\
\hline
\end{tabular}

Thus, as perthe discussion, the temperatures of the two citiesvary over the course of the year. Further, Yanbu is warmer than Tabuk because the sea lowers the temperature at night. 


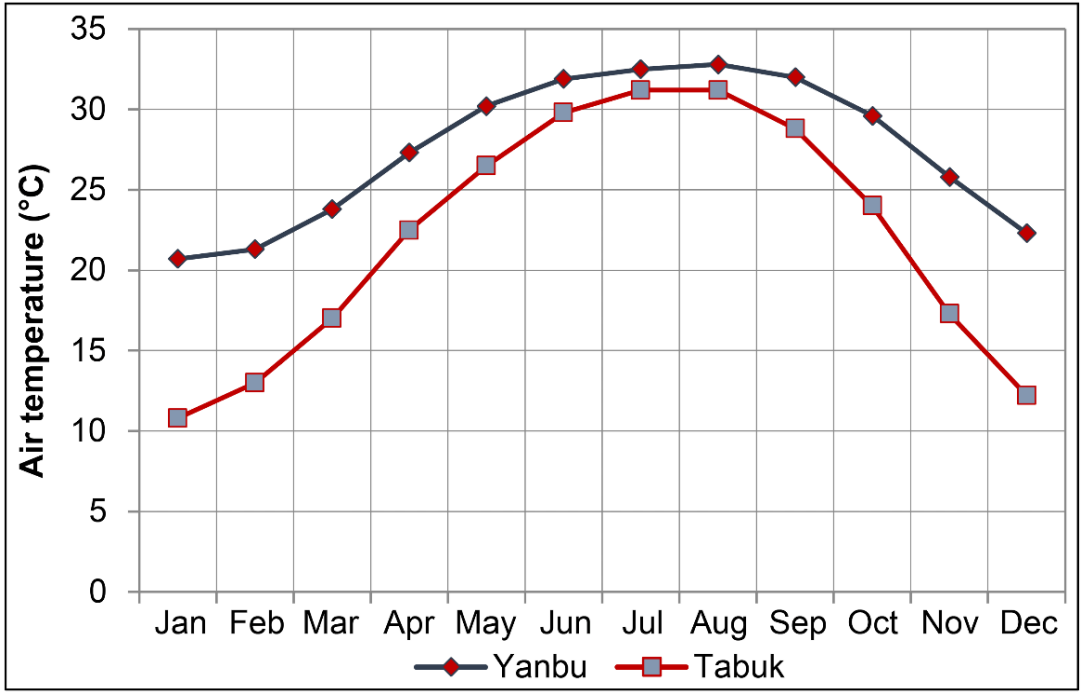

Figure 3. Comparison of monthly averages of air temperatures in Tabuk and Yanbu during 1978-2015.

\subsubsection{Relative Humidity:}

The humidity of a place is an important natural variable that is closely related to the prevailing climate (Saka, 1995). A number of factors influence the humidity of air, with the most important ones beingthe temperature and wind movement.

Tables (1) and (2) and Figure (4) show that the monthly average relative humidity in Tabuk reaches $49 \%$ in December and January, 34\% in March, $43 \%$ in November, and $24 \%$ in August. The relative humidity in Yanbu is higher than that in Tabuk owing to the proximity of the former to the Red Sea. The highest rates of relative humidity occur in October, August, March, and April (59, 56, 52, and 56\%, respectively).

The differences in the relative humiditiesof the two locations are attributable to their distance from the Red Sea. Yanbu is located on the Red Sea coast while Tabuk is far from the sea. Hence, in the latter case, there is no source of humidity except for the effect of the Mediterranean Sea, which occurs only during the winter.

\subsubsection{Pressure:}

The atmospheric pressure on the land surface as well as that in the atmosphere affects the horizontal and vertical movement of air. The study areasare affected by the subtropical high pressure that exists at latitudes higher 
than $30^{\circ} \mathrm{N}$ throughout the year within the range of the permanent high pressure there. This is evident when one compares the pressure conditions for the study areas during the different seasons of the year (Ahmed 2006).

In Tabuk, the highest average monthly atmospheric pressure occurs in December, reaching $930.0 \mathrm{mmhg}$ and then decreases to $923.1 \mathrm{mmhg}$ in June. On the other hand, the average monthly atmospheric pressure in Yanbu reaches 1013.6 mbar in January, while the lowest average monthly pressures recorded in June and August are 1002.1 mmhg and 1002.1 mmg, respectively (Figure 5).

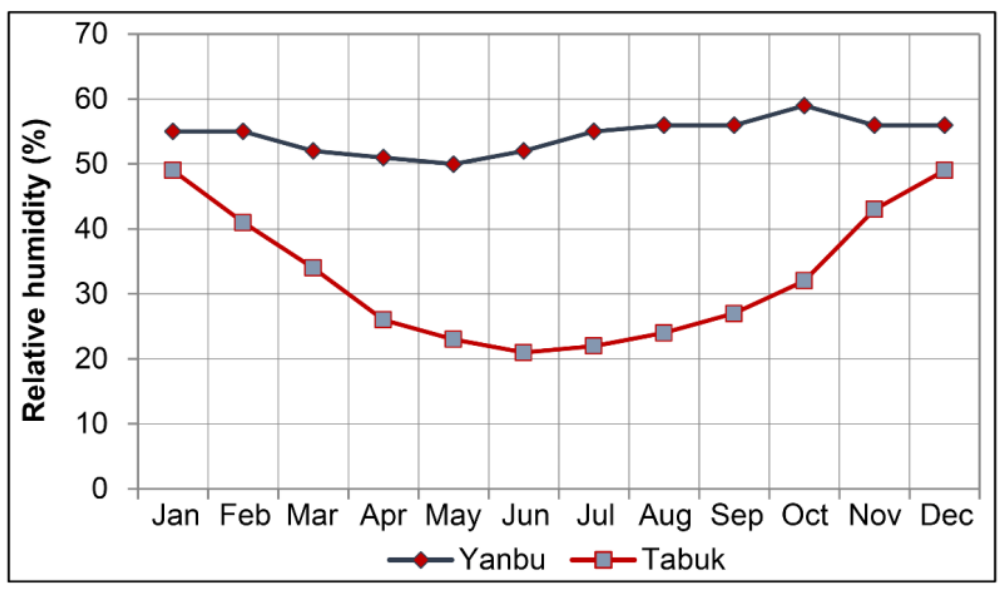

Figure 4. Comparison of monthly averages of relative humidity in Tabuk and Yanbu during 1978-2015.

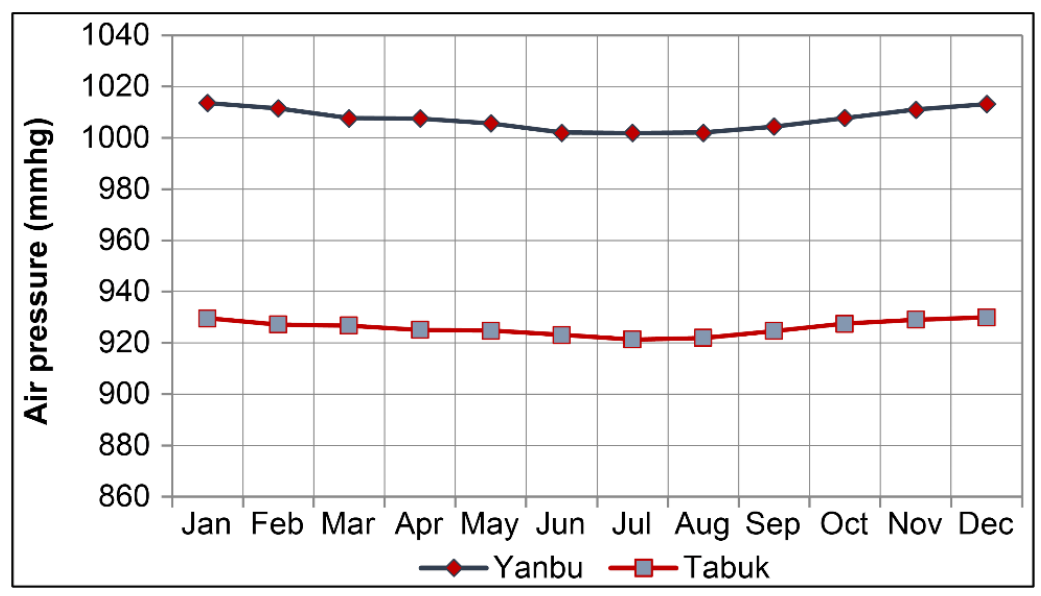

Figure 5. Comparison of monthly averages of air pressures in Tabuk and Yanbu during 1978-2015. 


\subsubsection{Precipitation:}

Precipitation in Saudi Arabia is characterized by significant annual fluctuations. It is also characterized by heavy rainfall accompanied by thunderstorms and severe weather disturbances (Ahmed 1993).

Tables (1) and (2) and Figure (6) show that the total amount of average monthly precipitation in Tabuk reaches $5635.7 \mathrm{~mm}$ in October, $4828 \mathrm{~mm}$ in December, and $4020.8 \mathrm{~mm}$ in November and decreases to $1576.2 \mathrm{~mm}$ in August. The precipitation increases during the autumn and winter because of the impact of the weather depressions, which bring rain. In Yanbu, the highest average monthly total precipitation reaches $3889.8 \mathrm{~mm}$ in September, $3140.7 \mathrm{~mm}$ in February, and $3125.1 \mathrm{~mm}$ in April. Further, the lowest measured average monthly precipitation is in July at $8.2 \mathrm{~mm}$.

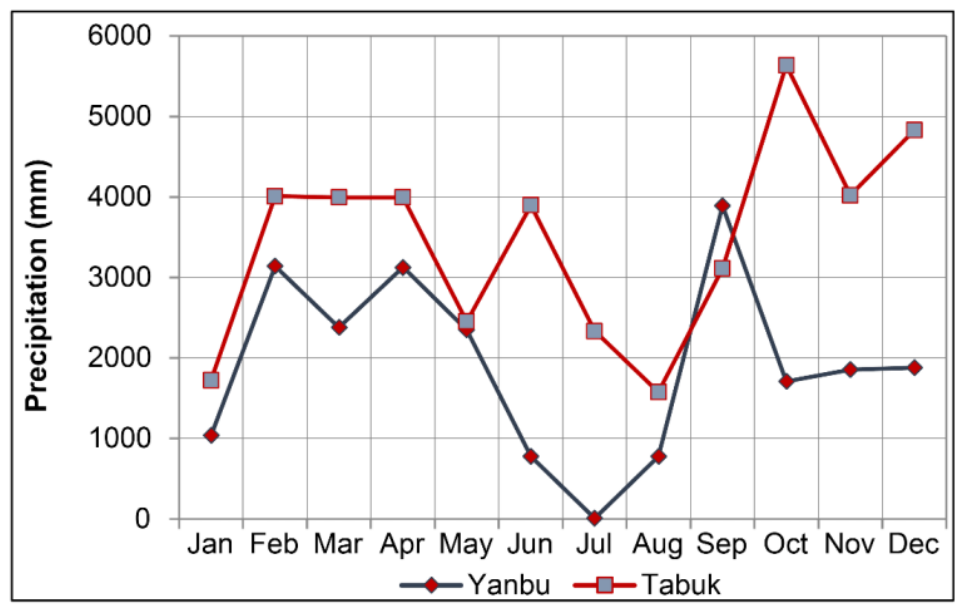

Figure 6. Comparison of average monthly precipitation levels in Tabuk and Yanbu during 1978-2015.

\section{Impact of Climate on Human Comfort}

Next, we discuss theprimary climate variables that affect human comfort in Tabuk and Yanbu, namely, the temperature, relative humidity, and wind speed. This is donebased on the most frequently used climate comfort indices, that is, the effective temperature based on Gaffney's coefficient, Siple and Passel's wind chill index, and Thom's thermal discomfort index.

\subsection{Effective temperature based on Gaffney's coefficient:}

Direct and indirect variations in the temperature have a significant impact on people and their daily activities. Therefore, many climate and environmental scientists have used the temperature as a bioclimatic index to 
infer the level of people's comfort in their surrounding environment, as it is the first climate variable that people respond to. Applied climatological studies have investigated the impact of the effective temperature, that is, the temperature at which human activity is affected owing to the physiological changes that result from exposure to thethermal changes related to the mutual relationships between the humidity, temperature, and wind speed (Oscar 1974). Many scientists have employed the effective temperature as a measure of human comfort and have set limits and standards for it. Table (3) lists Gaffney's classification scale for the effective temperature.

Table 3. Gaffney's classification scheme for effective temperatures.

\begin{tabular}{|l|l|}
\hline \multicolumn{1}{|c|}{$\begin{array}{c}\text { Effective } \\
\text { Temperature }\left({ }^{\circ} \mathbf{C}\right)\end{array}$} & \multicolumn{1}{c|}{ Type of Comfort } \\
\hline Less than 15 & Discomfort (cold) \\
\hline $15-17$ & A cold transitional phase between comfort and discomfort \\
\hline $17-25$ & Complete comfort \\
\hline $25-27$ & A warm transitional phase between comfort and discomfort \\
\hline $27-28$ & Discomfort (hot) \\
\hline More than 28 & Extreme discomfort \\
\hline
\end{tabular}

\section{Table (3) illustrates the following points:}

1. The effective temperature for human comfort is limited to $15-27{ }^{\circ} \mathrm{C}$ because these temperaturesconstitute a transitional phase between comfort and discomfort characterized by cold, while temperatures between $25-27{ }^{\circ} \mathrm{C}$ are a transitional phase between comfort and discomfort characterized by warmth.

2. People cannot cope with increases in the temperature beyond $27{ }^{\circ} \mathrm{C}$ and start feeling stressed when the effective temperature exceeds this limit.

3. People feel stressed and extremely uncomfortable if the temperature limit exceeds $28{ }^{\circ} \mathrm{C}$.

4. People also feel extreme discomfort if the temperature drops below $15^{\circ} \mathrm{C}$.

5. Gaffney considered the effective temperature limit, which is $35^{\circ} \mathrm{C}$, the maximum limit that humans can bear after which they feel stressed if the temperature rises. Some individuals may evenface health risks.

6. Gaffney suggested that playing sports and practicing other activities that require movement can help in lessening the feeling of discomfort caused by low effective temperatures.

Table (4) and Figures (7 and 8) show the results obtained when Gaffney's model was used for Tabuk and Yanbu to classify the type of comfort that is experienced in these cities based on their monthly average temperature. 
Table 4. Results of use of Gaffney's model for Tabuk and Yanbu.

\begin{tabular}{|c|c|c|c|c|}
\hline \multirow[b]{2}{*}{ Month } & \multicolumn{2}{|l|}{ Yanbu } & \multicolumn{2}{|l|}{ Tabuk } \\
\hline & 总 & 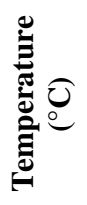 & 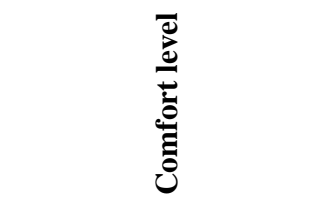 & 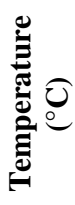 \\
\hline January & Complete comfort & 21 & Discomfort & 11 \\
\hline February & Complete comfort & 21 & Discomfort & 13 \\
\hline March & Complete comfort & 24 & Complete comfort & 17 \\
\hline April & Discomfort & 27 & Complete comfort & 22 \\
\hline May & Extreme discomfort & 30 & Transitional warm phase & 26 \\
\hline June & Extreme discomfort & 32 & Extreme discomfort & 30 \\
\hline July & Extreme discomfort & 32 & Extreme discomfort & 31 \\
\hline August & Extreme discomfort & 33 & Extreme discomfort & 31 \\
\hline September & Extreme discomfort & 32 & Extreme discomfort & 29 \\
\hline October & Extreme discomfort & 30 & Complete comfort & 24 \\
\hline November & Transitional warm phase & 26 & Complete comfort & 17 \\
\hline December & Complete comfort & 22 & Discomfort & 12 \\
\hline
\end{tabular}

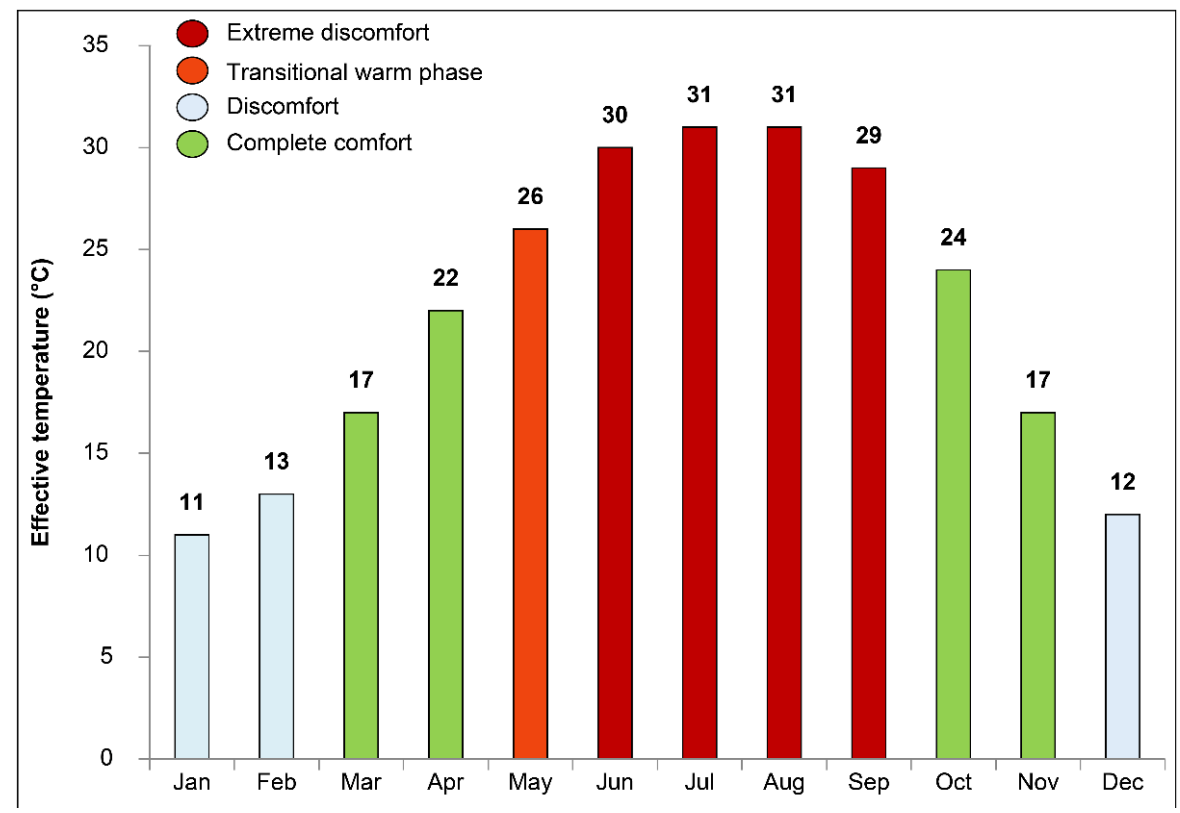

Figure 7. Results obtained using Gaffney's model for Tabuk. 


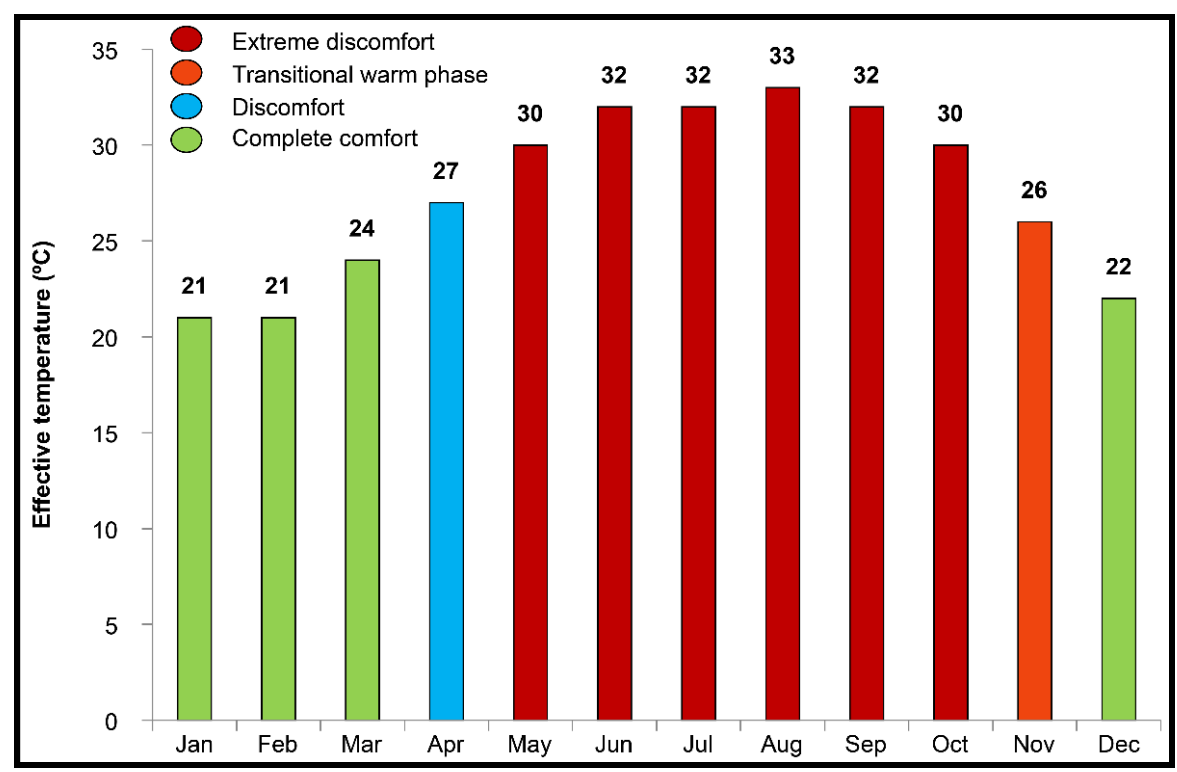

Figure 8. Results obtained using Gaffney's model for Yanbu.

This classification shows that there is a clear difference between Tabuk and Yanbu throughout the period of suitable comfort. Thus, we can arrive at the following conclusions:

1. The period ofcold discomfort wherein the temperature is less than $15^{\circ} \mathrm{C}$ extends throughout the winter in Tabuk, with the degree ofdiscomfort being the highest in January. Yanbu does not experience any thermal discomfort caused by low temperatures.

2. There is a transitional phase in May that is characterized by warmth in Tabuk, whereas Yanbu experiences a warm transitional period in November. The average temperature at both locations reaches $26{ }^{\circ} \mathrm{C}$.

3. The period of extreme discomfort as a result of high temperatures begins in Tabuk in June and lasts throughout the summer, includingduring September. In Yanbu,this period extends from May to October, with the temperature inAugust reaching almost $33{ }^{\circ} \mathrm{C}$.

4. The periods of complete comfort for Tabuk and Yanbu vary greatly. In Tabuk, the period of complete comfort corresponds to April and May (spring) as well as October and November (autumn). Conversely, for Yanbu, this period extends from December till March, that is, throughout the winter and early spring.

\subsection{Siple and Passel's wind chill index}

Siple and Passel developed a classification system for the comfort limits based on the wind chill index, as listed in Table (5). 
Table 5. Siple and Passel's wind chill index values and corresponding feelings.

\begin{tabular}{|l|l|}
\hline \multicolumn{1}{|c|}{ Wind chill index $\left(\mathbf{C a l} / \mathbf{m}^{2} / \mathbf{h}\right)$} & \multicolumn{1}{c|}{ Feeling } \\
\hline Less than 50 & Hot \\
\hline $50-100$ & Warm \\
\hline $100-200$ & Calm and refreshing \\
\hline $200-400$ & Tends to be cold \\
\hline $400-600$ & Tends to be even colder \\
\hline $600-800$ & Cold \\
\hline $800-1000$ & Very cold \\
\hline $1000-1200$ & Chilly \\
\hline $1200-1400$ & Uncovered meat freezes \\
\hline $1400-2000$ & Uncovered meat freezes in a minute \\
\hline $2000-2500$ & Unbearable \\
\hline
\end{tabular}

Tables (6) and (7) list the results obtained using Siple and Passel's wind chill index model to determine the human feeling of comfortbased on the monthly average temperature and wind speed in the cases of Tabuk and Yanbu.

\section{a. Use of wind chill index in case of Tabuk:}

The results obtained afterusing thewind chill index for Tabuk show that the cold period extends throughout the year such that the temperature reaches the freezing point and even falls below it, making the climate unbearable. This period lasts throughout the winter and early spring.

Table 6. Siple and Passel's wind chill index values for Tabuk.

\begin{tabular}{|l|c|c|c|l|}
\hline Month & $\begin{array}{c}\text { Comfort } \\
\text { index } \\
(\mathbf{K})\end{array}$ & $\begin{array}{c}\text { Average } \\
\text { temperature } \\
\left({ }^{\circ} \mathbf{C}\right)\end{array}$ & $\begin{array}{c}\text { Wind } \\
\text { speed } \\
(\mathbf{m} / \mathbf{s})\end{array}$ & \multicolumn{1}{|c|}{ Classification } \\
\hline Jan & 2152 & 11 & 2.2 & Unbearable \\
\hline Feb & 1862 & 13 & 2.8 & Uncovered meat freezes in a minute \\
\hline Mar & 1443 & 17 & 3.2 & Uncovered meat freezes in a minute \\
\hline Apr & 936 & 22 & 3.4 & Very cold \\
\hline May & 584 & 26 & 3.3 & Tends to be cold \\
\hline Jun & 287 & 30 & 3.2 & Tends to be cold \\
\hline Jul & 160 & 31 & 3.2 & Nice and refreshing \\
\hline Aug & 168 & 31 & 3.0 & Nice and refreshing \\
\hline Sep & 393 & 29 & 2.8 & Tends to be cold \\
\hline Oct & 864 & 24 & 2.4 & Very cold \\
\hline Nov & 1533 & 17 & 2.1 & Uncovered meat freezes in a minute \\
\hline Dec & 2059 & 12 & 1.9 & Unbearable \\
\hline
\end{tabular}




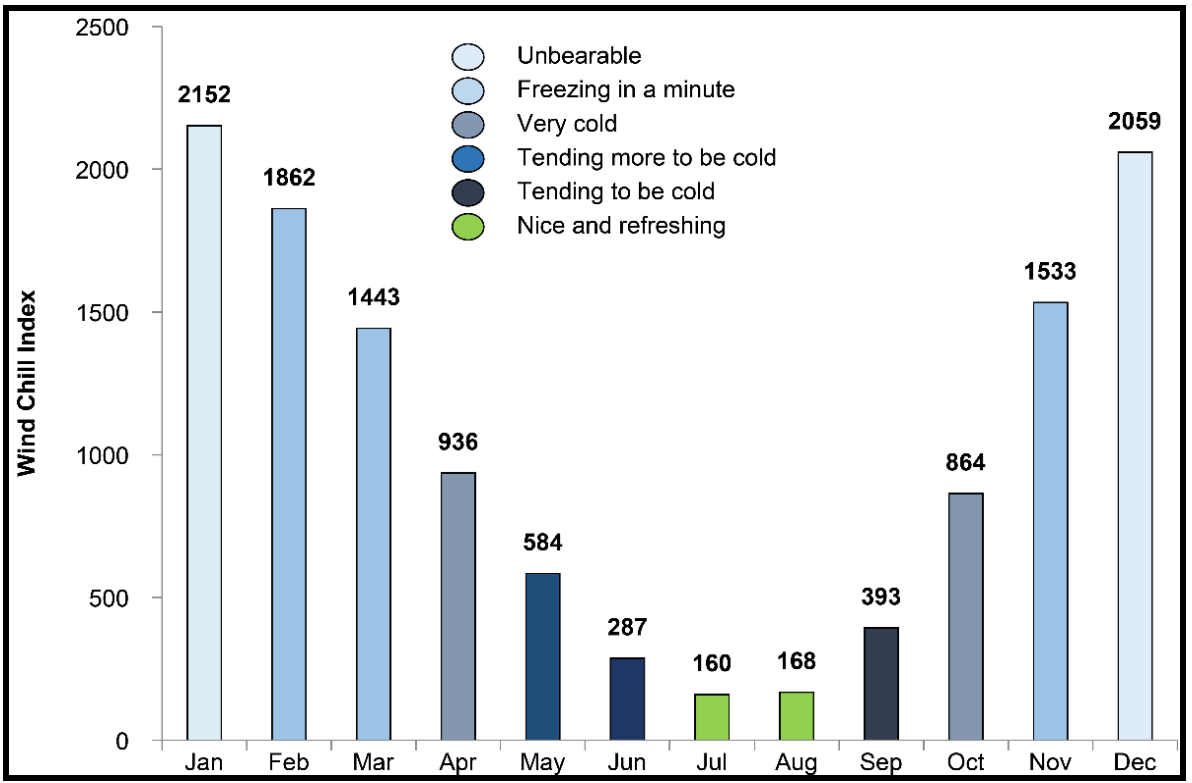

Figure 9. Siple and Passel's wind chill index values for Tabuk.

Table (6) and Figure (9) show the periods of different climatic comfort levels for Tabuk based on Siple and Passel's wind chill index.

1. A period when the temperature is unbearably lowextends through December and January (winter).

2. A periodwhen it is freezing occurs from February to March (end of the winter and beginning of spring) and in November (end of autumn).

3. A period when it is very cold occurs during April (middle of spring) and October (middle of autumn).

4. The period when it ismoderately cold is limited to May, that is, to the end of spring.

5. A period when it isslightly cold occurs during June and September.

6. Period when the climate is nice andenjoyableis a short one and occurs for a maximum of two months, during July and August (summer).

\section{b. Use of wind chill index in case of Yanbu:}

Based on the results obtained by usingthe wind chill index for Yanbu,it can be concluded that there occur periods of climate variationswherein the climate fluctuates between hot and extreme cold. Further, there are no periods where the climate is comfortable (Table 7). 
Table 7. Siple and Passel's wind chill index values for Yanbu.

\begin{tabular}{|l|c|c|c|l|}
\hline Month & $\begin{array}{c}\text { Comfort } \\
\text { Index }(\mathbf{K})\end{array}$ & $\begin{array}{c}\text { Average } \\
\text { Temperature }\left({ }^{\circ} \mathbf{C}\right)\end{array}$ & $\begin{array}{c}\text { Wind } \\
\text { speed }(\mathbf{m} / \mathbf{s})\end{array}$ & \multicolumn{1}{|c|}{ Classification } \\
\hline Jan & 1104 & 21 & 3.3 & Severe cold \\
\hline Feb & 1031 & 21 & 3.5 & Severe cold \\
\hline Mar & 788 & 24 & 3.9 & Cold \\
\hline Apr & 485 & 27 & 3.9 & Tends to be cold \\
\hline May & 231 & 30 & 4.1 & Tends to be cold \\
\hline Jun & 89 & 32 & 4.6 & Warm \\
\hline Jul & 41 & 32 & 4.5 & Hot \\
\hline Aug & 20 & 33 & 4.5 & Hot \\
\hline Sep & 86 & 32 & 4.0 & Warm \\
\hline Oct & 307 & 30 & 3.3 & Tends to be cold \\
\hline Nov & 658 & 26 & 3.0 & Cold \\
\hline Dec & 986 & 22 & 3.0 & Very cold \\
\hline
\end{tabular}

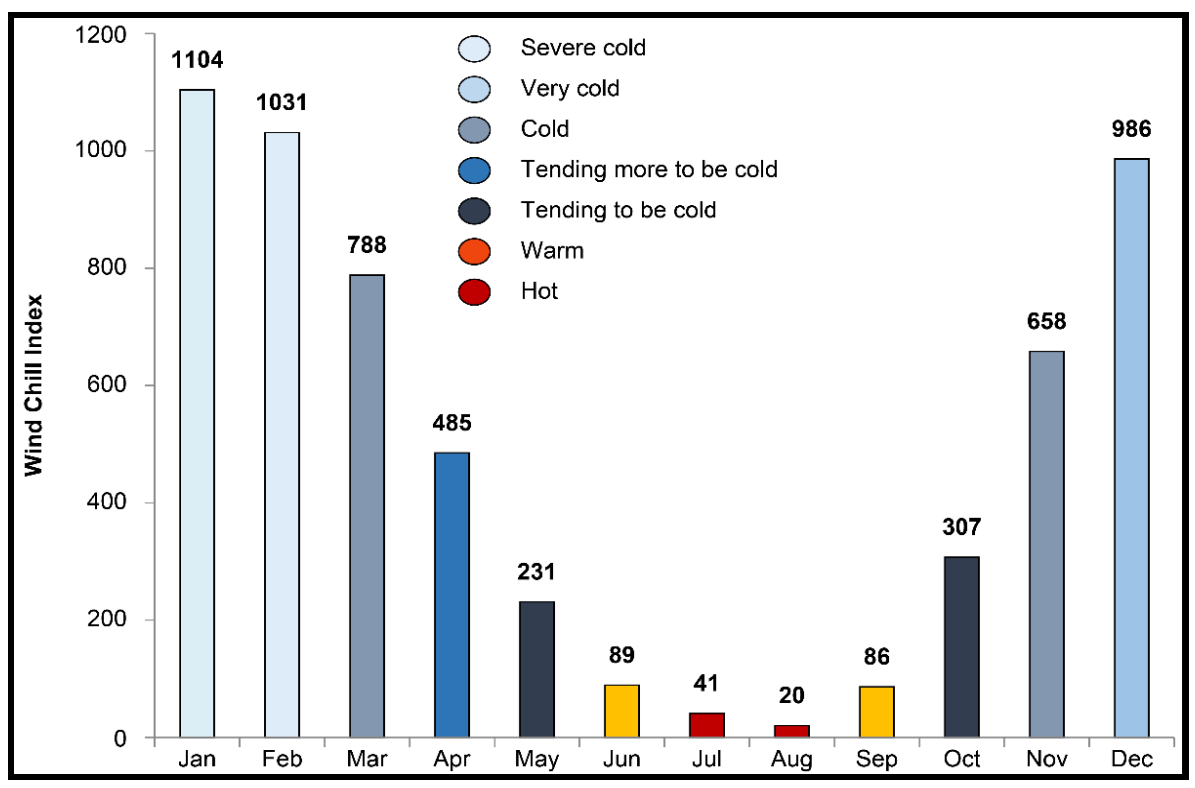

Figure 10. Siple and Passel's wind chill index values for Yanbu. 
Table (7) and Figure (10) illustrate the classification of the climate comfort periods for Yanbu based on the wind chill index.

1. A period when it is unbearably coldextends for two months during January and February (winter).

2. The period when it is extremely cold is limited to December, that is, to the beginning of the winter.

3. A period when it is very cold occurs between March (mid spring) and November (the end of autumn).

4. A period when it is moderately cold occurs in the middle of the spring during April.

5. A period when it is slightly coldoccurs during May and October.

6. A period when it is warm occurs during June and September, that is, at the beginning and end of the summer.

7. A period when it is hot occurs during July and August when the temperature rises to its maximum of almost $33^{\circ} \mathrm{C}$.

\subsection{Thom's thermal discomfort index:}

A number of researchers have tried toelucidatethe combined effect of the temperature and relative humidity on human comfort and activity,given the obviousindividual effects of these parameters. As per Thom's thermal threshold classification system, a discomfort index is used to analyze the climate in order to determine the physiological effects of heat and humidity on the human body (Table 8).

Table 8. Classifications based on Thom's thermal discomfort index.

\begin{tabular}{|l|l|}
\hline \multicolumn{1}{|c|}{$\begin{array}{c}\text { Discomfort } \\
\text { index (DI) }\end{array}$} & \multicolumn{1}{c|}{ Type of comfort } \\
\hline $\mathrm{DI}<10$ & Extreme discomfort (cold) \\
\hline $10<\mathrm{DI}<15$ & Medium discomfort (cold) \\
\hline $15<\mathrm{DI}<18$ & Relative comfort (cold) \\
\hline $18<\mathrm{DI}<21$ & Complete comfort \\
\hline $21<\mathrm{DI}<24$ & Relative comfort (warm, 10-50\% of people feel uncomfortable) \\
\hline $24<\mathrm{DI}<27$ & Medium discomfort (hot, 100\% of people feel uncomfortable) \\
\hline $27<\mathrm{DI}<29$ & Extreme discomfort \\
\hline $\mathrm{DI}>29$ & Dangerous to health (hot) \\
\hline
\end{tabular}

Table (9) and Figures (11 \& 12) show the results of the use of Thom's discomfort thermal index in the cases of Tabuk and Yanbu for identifying the degrees of human climatic comfort based on the monthly average data for the dry bulb temperature and relative humidity. 
Table 9. Variations in Thom's thermal discomfort index values for Tabuk and Yanbu.

\begin{tabular}{|c|c|c|c|c|c|}
\hline \multicolumn{2}{|c|}{ Tabuk } & \multicolumn{2}{|c|}{ Yanbu } & Type of Comfort & Discomfort Index \\
\hline- & - & - & - & Extreme discomfort (cold) & DI $<10$ \\
\hline $\begin{array}{l}\text { January } \\
\text { December } \\
\text { February }\end{array}$ & $\begin{array}{l}12 \\
13 \\
14\end{array}$ & - & - & Average discomfort (cold) & $10<\mathrm{DI}<15$ \\
\hline $\begin{array}{l}\text { March } \\
\text { November }\end{array}$ & $\begin{array}{l}16 \\
16\end{array}$ & - & - & Relative comfort (cold) & $15<$ DI $<18$ \\
\hline $\begin{array}{l}\text { April } \\
\text { October }\end{array}$ & $\begin{array}{l}19 \\
20\end{array}$ & $\begin{array}{l}\text { January } \\
\text { February } \\
\text { December }\end{array}$ & $\begin{array}{l}19 \\
20 \\
20\end{array}$ & Complete comfort & $18<\mathrm{DI}<21$ \\
\hline $\begin{array}{l}\text { May } \\
\text { June } \\
\text { September }\end{array}$ & $\begin{array}{l}21 \\
23 \\
23\end{array}$ & $\begin{array}{l}\text { March } \\
\text { November }\end{array}$ & $\begin{array}{l}21 \\
23\end{array}$ & Relative comfort (warm) & $21<\mathrm{DI}<24$ \\
\hline $\begin{array}{l}\text { July } \\
\text { August }\end{array}$ & $\begin{array}{l}24 \\
24\end{array}$ & $\begin{array}{l}\text { April } \\
\text { May } \\
\text { October }\end{array}$ & $\begin{array}{l}24 \\
26 \\
26\end{array}$ & Average discomfort (hot) & $24<\mathrm{DI}<27$ \\
\hline- & - & $\begin{array}{l}\text { June } \\
\text { July } \\
\text { August } \\
\text { September }\end{array}$ & $\begin{array}{l}27 \\
28 \\
28 \\
28 \\
\end{array}$ & Extreme discomfort (hot) & $27<$ DI $<29$ \\
\hline - & - & - & - & Great danger to health & DI $>29$ \\
\hline
\end{tabular}

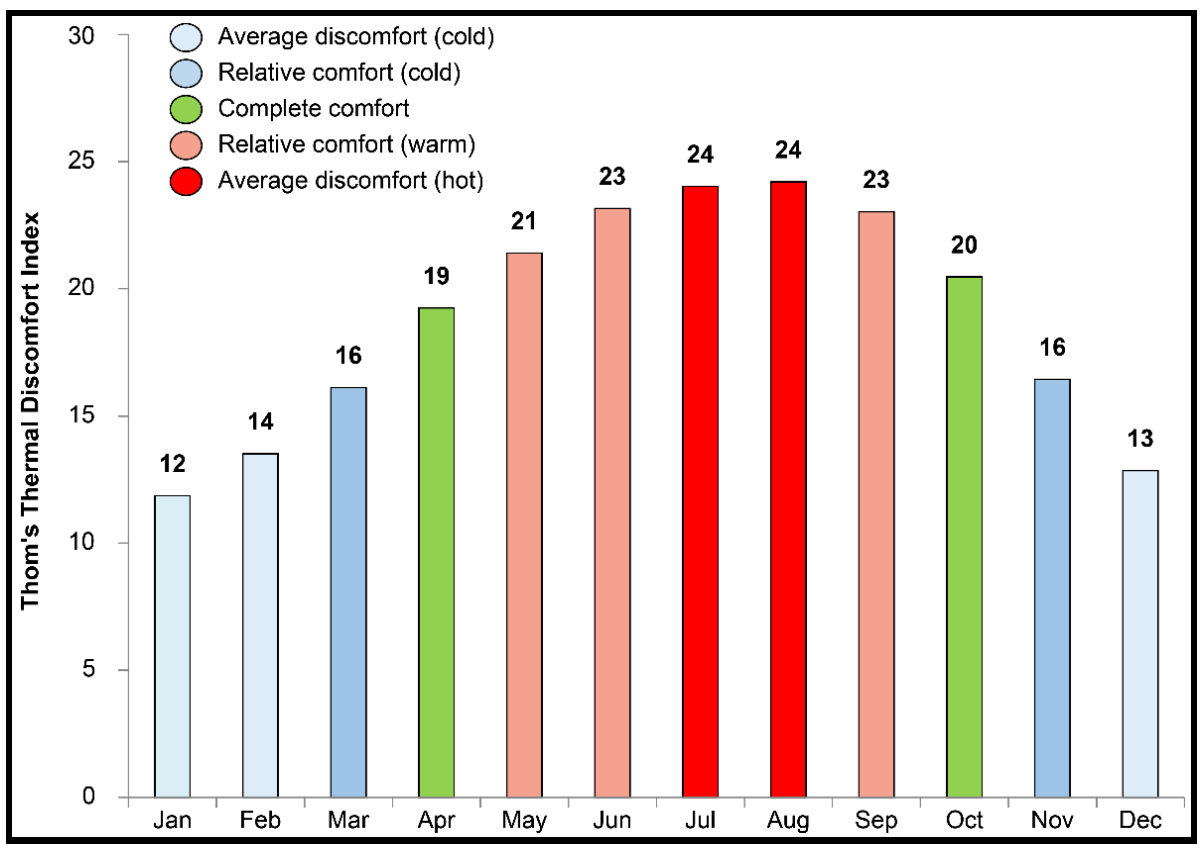

Figure 11. Thom's thermal discomfort index values for Tabuk. 


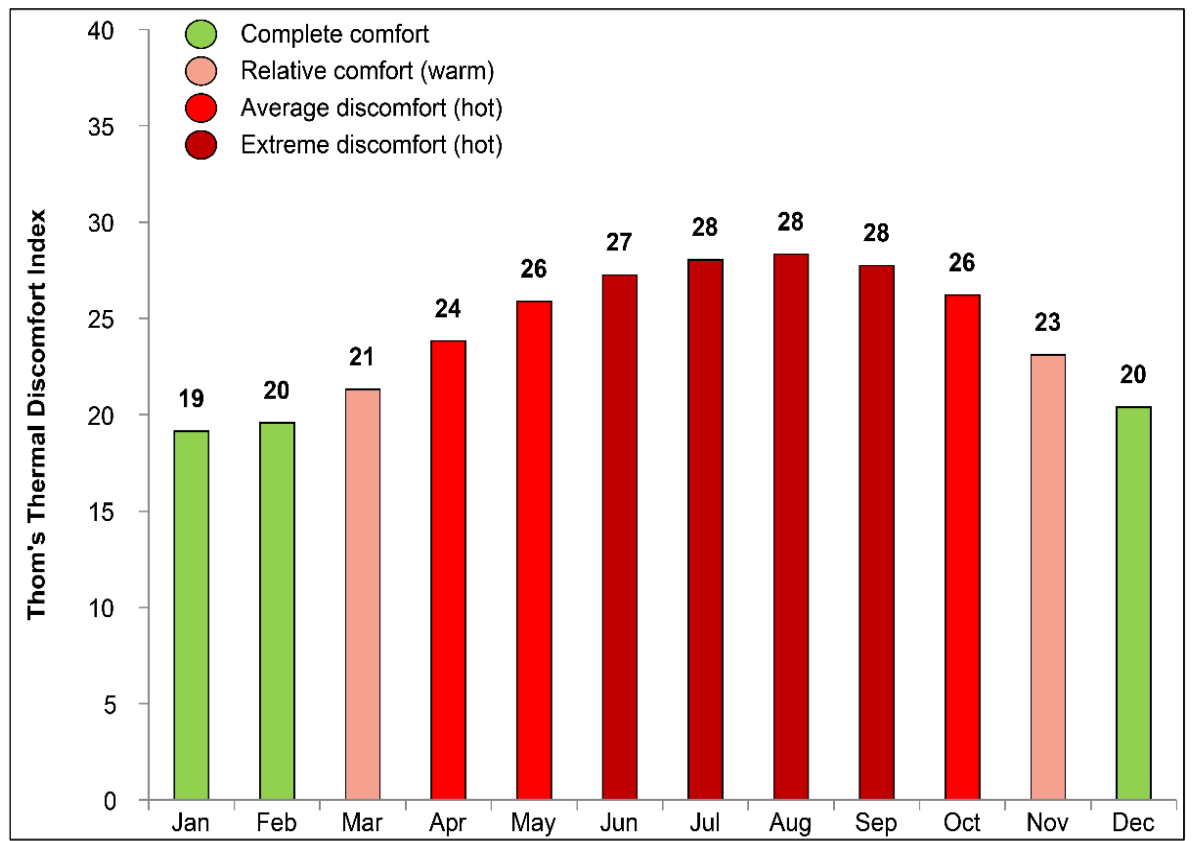

Figure 12. Thom's thermal discomfort index values for Yanbu.

Table (9) and Figures (11 and 12) show the periods of thermal discomfort in Tabuk and Yanbu.

1. A cold period with an average degree of discomfort extends in Tabuk for three months, that is, for December, January and February (the entire winter season).

2. A cold period of relative comfort prevails during March and November in Tabuk.

3. A period of complete comfort occurs in Tabuk from April and October and in Yanbu from December to February (the entire winter season).

4. A warm period of relative comfort lasts through May, June, and September in Tabuk and through March and November in Yanbu.

5. A hot period with an average degree of discomfort occurs in Tabuk during July and August, while in Yanbu, it occurs in April, May, and October.

6. A hot period of extreme discomfort occursin Yanbu through June, July, August, and September, that is, over the entire summer and a month into early autumn. 


\section{Conclusion and Recommendations}

\subsection{Conclusion:}

In this study, we evaluated the impact of the Red Sea on the climatic features of Tabuk and Yanbu and used several comfort indices to determine the most suitable climatic conditions.

\section{The main results of the study can be summarized as follows:}

1. The temperatures in Tabuk and Yanbu vary throughout the year. Yanbu is warmer than Tabuk because the breeze from the Red Sea lowers the temperature.

2. The wind speed in Tabuk is higher than that in Yanbu because of the higher altitude of Tabuk. In fact, the higher the altitude of a place, the higher the wind speed will be.

3. The relative humidity in Yanbu is greater than that in Tabuk because of its proximity to the Red Sea.

4. Despite the scarcity of rain, the effect of the lack of rainfall in Tabuk and Yanbu was evident duringsummer. Rain mainly falls during autumn and winter because of the impact of depressions that bring rain.

5. Based on Gaffney's model there is a clear difference between Tabuk and Yanbu in terms of the length of the suitable comfort period. We find that a cold period of discomfort where the temperature is less than $15{ }^{\circ} \mathrm{C}$ exists throughout the winter in the case of Tabuk, with January being the month with the maximum discomfort. Yanbu does not experience any periods of discomfort owing to its low temperature. There is a transitional phase in May characterized by warmth in the case of Tabuk, while the warm transitional period for Yanbu occurs in November when the average temperature reaches 26 ${ }^{\circ} \mathrm{C}$. A period of extreme discomfort because of high temperature begins in Tabuk at the start of June and lasts for the entire summer through September. However, for Yanbu, this period extends through May and October, with the temperature in August being almost 33 ${ }^{\circ} \mathrm{C}$. The periods of complete comfort for Tabuk and Yanbu differ greatly. In Tabuk, this period occursin March and April (spring) as well as in October and November (autumn). In Yanbu,this period extends from December to March, that is, throughout the winter and early spring.

6. The wind chill index values for Tabuk showed that cold periods occur for most of the year, with the temperaturedipping to the freezing point and even lowerto unbearable levels. These periods also extend throughout the winter and early spring. Based on the 
wind chill index, it can be concluded that the climate of Yanbu experiences periods of variations wherein the climate fluctuates between hot and extreme cold. However, there are no periods of comfortable climate.

7. Based on Thom's thermal discomfort index, the periods of thermal discomfort for Tabuk and Yanbu can be classified as follows:

- A cold period of average discomfort occurs in Tabuk during December, January and February (the entire winter).

- A cold period of relative comfort occurs in Tabuk during March and November.

- Tabuk experiences periods of complete comfort during April and October, while Yanbu experiences these periods during December, January, and February (the winter season).

- A warm period of relative comfort occurs in May, June, and September in Tabuk, while in Yanbu, it occurs in March and November.

- A hot period of average discomfort occurs in Tabuk during July and August while in Yanbu, it occurs in April, May, and October.

- A hot period of extreme discomfort occurs uniquely in Yanbu from June to September, that is,for the entire summer season and a month into early autumn.

\subsection{Recommendations:}

To alleviate the thermal burden of the inhabitants of Tabuk and Yanbu and to raise individual productivity, we present a few recommendations that should be taken into consideration during future planning endeavors and when conducting scientific research in this field. The main recommendations are as follow:

1. Necessary precautions must be taken to drink enough fluids and wear protective clothing that ensures the individual's safety and protects against the sun during the hot months and against low temperatures during the cold months.

2. Attention should be paid to the type of clothes worn. Further, individuals should protect themselves against exposure to sharp decreases in the temperature during certain months when they feel discomfort, as this can affect health and productivity. The inhabitants of coastal areas such as Yanbu should wear light and loose cotton clothing, as such fabrics are highly absorbent and permeable. Air circulation through these clothes aidsthe evaporation of sweat from the body, leading to cooling. 
3. It is important to select the appropriate building materials that suit the climate conditions during the different seasons of the year. It is also important to use suitable thermal insulators that can help in the storage of thermal energy and reflect the greatest amount of solar radiation.

\section{Finding}

This research was funded by the Deanship of Scientific Research at Princess Nourahbint Abdulrahman University through the Fast-track Research Funding Program.

\section{List of Literature}

1. Ahmed, B.M. (1993): Climate of Saudi Arabia. Geography Theses, The Kuwaiti Geographic Society, 157.

2. Ahmed, B.M. (2006):extreme climatic elements in Saudi Arabia. Series of special editions, Gulf and Arabian Peninsula Studies Center, Kuwait University, 16.

3. Aljukhaidib, M.A. (1991): Climate and Human Comfort in Al-Qassim Region. Fourth Geographic Seminar held by Geography Departments in Saudi Arabia, 24-26 December, Mecca.

4. Bakharjy, F. (1989): The Impact of climate conditions on the inhabitants of cities in Saudi Arabia. Unpublished Master's thesis, Department of Geography, King Saud University.

5. Habib, B.O. (2004): Physiological comfort regions in Saudi Arabia (Application of Terjung's Model). Geographical Studies Series, Saudi Geographical Society, King Saud University.

6. Habib, B.O. (2006): Temperature of warming and cooling days at varying temperature thresholds in the eastern region and its relationship to energy consumption (A Study in Applied Climatology). Saudi Geographical Society, King Saud University, 80.

7. Musa, A.H. (2002): Bioclimate. Damascus: Ninawa Studies, Publishing and Distribution.

8. Oscar, V.G. (1974): Glossaire de météorologie et de climatologie. Paris: Les Presses de l'Université Laval.

9. Qerba, J.M. (2004): The in Riyadh in Saudi Arabia. A research presented to the symposium of tourism in Saudi Arabia, the components and possibilities held in King Saud University, Department of Geography for the period 1315/5/2002. Published in the Arab Geographical Magazine, Part II, 36, 44, Cairo.

10. Saka, A.H.A. (1995): The Natural geography of Saudi Arabia, p. 90.

11. Shehadeh, N. (1983): Practical Climate. University of Jordan, 2, 181.

12. Siple, P.A., Passel, C.F. (1945): Measurements of dry atmospheric cooling in subfreezing temperatures. Proc. Amer. Philos. Soc., 89: 177-199. 
13. Suliman, B.F. (1991): Bioclimate analysis and assessment of the buildings' design of the climatic region of the holy city of Mecca. A research presented to the fourth symposium of the departments of geography in the Kingdom, Umm Al-Qura University, Makkah 18-20 Jumada Alakhera, 1412.

14. Tarek, Z.S. (2003): Climate and human comfort in Asir. Middle East Journal, Ain Shams University.

15. Thom, E.C. (1959): The Discomfort Index. Weatherwise, 12: 57-60. 


\section{الملخص العربى}

يعالج البحث تأثثر البحر الأحمر على السمات المناخية لمدينتي تبوك وينبع في المملكة العربية السعودية وتم فيه استخدام مؤشرات راحة مختلفة لتحديد الظروف المناخية الأكثر ملاعمة لهذه المدن. وتبين أن هناك فرقًا واضحًا بين تبوك وينبع فيما يتعلق بطول فترات الراحة. حيث تشهر رته

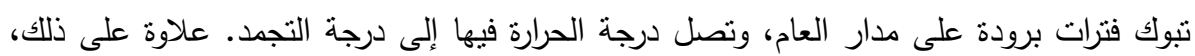

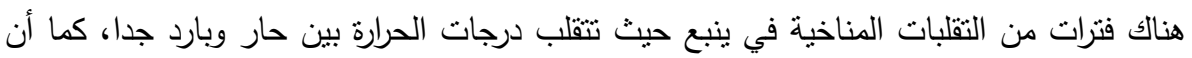
هناك عدة فترات من الانزعاج وعدم الارتباح الحراري في تبوك وينبع، خاصة خلال فصلي الثتاء والصبف. 